\title{
Reklam Çekiciliğinin ve Reklam Stratejilerinin Farklı Cinsiyetlerde Yarattığı Algının Dezenfektan Reklamları Üzerinden Değerlendirilmesi ${ }^{1}$
}

\author{
DOI: 10.26466/opus.833604
}

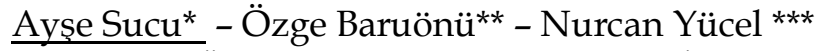 \\ * Doğuş Üniversitesi, Sosyal Bilimler Enstitüsü, İstanbul/Türkiye
}

E-Posta: ayse.sucu@marmara.edu.tr

ORCID: 0000-0001-7100-6344

** Dr. Öğr. Üyesi, Doğuş Üniversitesi, İktisadi ve İdari Bilimler Fakültesi, İstanbul, Türkiye

E-Posta: obaruonu@dogus.edu.tr

ORCID: $\underline{0000-0001-5533-775 X}$

*** Doç. Dr., Frrat Üniversitesi, İktisadi ve İdari Bilimler Fakültesi, Elazığ/Türkiye

E-Posta: nyucel@firat.edu.tr

ORCID: $\underline{0000-0002-6845-1284}$

Öz

İsletmelerin pazarlama karar ve stratejilerinin belirlenmesinde cinsiyet kavramı, etkili bir pazar bölümleme değişkenidir. Ürünlerin ve hizmetlerin hedef kitlenin isteklerine ve ihtiyaçlarna hitap edebilmesi, hedef kitlenin dikkatini çekebilmesi etkin bir pazarlama iletişimi ile mümkün olabilmektedir. Satın alma davranışın önemli ölçüde şekillendiren reklamlar, pazarlama iletiş̧imi açısından hedef kitleye ulaşmada anahtar rol üstlenmektedir. Hedef kitlenin, reklamı yapllan ürüne veya hizmete dikkatinin çekilmesi, ürünün veya hizmetin akılda kahıcllğının sağlanması, rakiplerinden ayırt edilebilir olması için geliştirilen unsurlar ifade eden reklamda çekicilik ve strateji, bu çalı̧̧ma ile irdelenen başlklar arasındadır. Bu kapsamda dezenfektan reklamlarnda kullanilan görsellerin reklamda çekicilik ve strateji oluştururken cinsiyet kaynakll; algllama farklllkkları, dikkat süre ve sayllarndaki farklllklar, nöropazarlama araştırma tekniklerinden Eye-Tracking yöntemi ile ortaya konulmaya çalışlmıştır. Bu çalışma; Fırat Üniversitesi Pazarlama ve Nöropazarlama Araştırma Merkezi kapsamında 15 kadin ve 15 erkek olmak üzere toplam 30 gönüllü katıllmon ile gerçekleştirilmiştir. Araştırmada, hedef kitlenin Eye Tracking analiz yöntemi ile dezenfektan reklamlarında kullanilan görsellerin farkındallk dïzeyleri araştırlmış ve görsel etki düzeyleri belirlenmiştir. Bu sebeple, dezenfektan reklamları aracilı̆̆ ile kadın ve erkeğin marka seçimindeki farklı kararlarminn altında yatan gerçek sebepler anlaşılmaya çalışılmıştır. Böylece, dezenfektan reklamlar üzerindeki görsel etki düzeylerinin cinsiyete göre farkllaşma düzeyleri tespit edilmiştir.

Anahtar Kelimeler: kadin-erkek, reklam stratejisi-reklam çekiciliği, nöropazarlama

\footnotetext{
${ }^{1}$ Bu makale Ayşe SUCU'nun makale ile aynı başıklı yüksek lisans tezinden üretilmiştir.
} 


\title{
The Evaluation of the Perception of Advertising Attractiveness and Advertising Strategies in Different Genders over Disinfectant Ads
}

\begin{abstract}
The concept of gender is an effective market segmentation variable in determining businesses' marketing decisions and strategies. With effective marketing communication, it is possible that products and services can address the target audience's demands and needs and attract the attention of the target audience. In terms of marketing communication, the ads that shape buying behavior significantly play a key role in reaching the target audience. The attractiveness and strategy of the advertisement, which expresses the elements developed to attract the target audience's attention to the advertised product or service, to ensure the permanence of the product or service, and to be distinguished from its competitors, are among the topics discussed in this study. In this context, the visuals used in disinfectant advertisements are based on gender while creating attraction and strategy in advertising; Understanding and interpreting information, differences in attention span and numbers, and neuromarketing research techniques are tried to be set forth by Eye-Tracking method.

This study was held with a total of 30 volunteers (15 women and 15 men) within the scope of the University of Firat, Marketing and Neuromarketing Research Center. In the research, the awareness level of the visuals used in disinfectant advertisements were investigated by the Eye Tracking analysis method of the target audience, and the visual effect levels were determined. For this reason, the real motives underlying the different decisions of men and women in brand selection were tried to be understood through disinfectant advertisements. Thus, differentiation levels of visual effects levels on disinfectant ads by gender were examined.
\end{abstract}

Keywords: gender, advertising strategy-attractiveness of advertisement, neuromarketing 


\section{Giriş}

Pazarlama araştırmalarında, önemli bir pazar bölümleme değişkeni olan cinsiyet kavramı, hedef pazarlara uygun etkili reklam stratejilerinin belirlenmesinde hem akademisyenlerin hem de reklam profesyonellerinin artan bir ilgisine sahip olmuştur. Özellikle pazarlama iletişimi ve reklamcılık alanları cinsiyetler arasındaki benzerlikleri ve farklılıkları betimlemeye çalışmıştır. Farklı disiplinler aracılığı ile yapılan pek çok araştırma (Linn ve Petersen, 1985; Roopnarine, 1986; Wilson, 1989; Bradley vd., 2001; Koç, 2002; Leeb ve Rejskind, 2004; Çiftçi, 2011; Pace, 2011; Şener, 2015; Uzbay, 2018) kadının ve erkeğin bilgiyi işleme ve iletişim süreçlerinde farklılıkların olduğunu ortaya koymuştur. Pazarlama ve reklamcllık alanında faaliyet gösterenlerin hedef kitle ile iletişime geçip etkili bir reklam mesajı oluşturabilmesinde bu bulguların araştırılması önemli bir seçenektir. Pazarlama araştırmalarında yeni teknolojik yöntemlerin kullanılmaya başlaması ile birlikte tüketicilerin ürünleri ve hizmetleri hakkında ne düşündüğünü önemseyen işletmeler ve araştırmac1lar çalışmalarında nöropazarlama yöntemlerini ve araçlarını da kullanmaya başlamıştır. Böylece, pazarlama alanındaki hızlı değişimler ile birlikte tüketici algısının öğrenilme isteği, tüketici algısına dayalı pazarlama stratejilerinin gelişimi de hız kazanmıştır (Ural, 2008, s.421-432).

Satın alma davranışına yön veren ve önemli bir pazarlama aracı olan reklamlar, belirlenen stratejiler ile hedef kitleyi etkileme gücüne sahiptir. Hedef kitlenin isteklerine ve ihtiyaçlarına hitap edebilmek ve etkili reklam oluşturmak güncel araştırma yöntemlerinin çalışmalarda kullanılmasını zorunlu hâle getirmiştir. Bu sebeple, pazarlama alanında gerçekleşen bu yenilikçi eğilimler sayesinde söz konusu araştırma göz tarama (Eye-Tracking) yöntemi ile gerçekleştirilmiştir.

\section{Bilimsel Yaklaşımlar Işığında Cinsiyete Dair Açıklamalar}

Biyolojik farklılıkların temeli; kromozomlar, hormonlar ve beyin yapısındaki farklılıklardan ileri gelmektedir. Sağlıklı bir insan hücresinde 46 kromozomun her biri cinsiyetin en küçük yapı taşını oluşturmaktadır. Kadın, yumurtaya $X$ kromozomu ile katkıda bulunurken; erkeğin katkısı $X$ olduğunda kız bebek, Y olduğunda ise erkek bebek dünyaya gelmektedir. Diğer bir ifadeyle embriyonun cinsiyeti erkeğin genetik katkısı ile belirlenmektedir (Moir ve 
Jessel, 1992, s.25-26). Cinsiyetin belirlenmesinde kromozomlar etkili iken kromozomlar da hormonlar aracılığ i ile vücut yapısını ve davranışları etkilemektedir. Başlangıçta bütün ceninler dişi olarak gelişmektedir. Ancak beyin de dâhil olmak üzere bebeğin vücut yapısının tamamı üzerinde etkili olan erkeklik hormonu testosteronun varlığı ile bu durum değişime uğramakta diğer bir ifadeyle cinsiyetler arasındaki beyin işlev farklılıkları ve bununla birlikte anatomik yapıdaki değişiklikler anne karnından itibaren oluşmaya başlamaktadır (Wilson, 1989, s.26-28).

Kadınların ve erkeklerin beyin yapısı üzerinde önemli sayılabilecek farklılıklar bulunmaktadır. Bireylerin davranışlarındaki farklılıklar hormonlarla beyin arasındaki etkileşime bağlı olmakla beraber bebek daha anne karnındayken sinirsel ağın ne şekilde yerleşeceği hormonlar tarafından belirlenmektedir (Moir ve Jessel, 1992, s.41-42). Zekânın cinsiyet ile ya da cinsiyete bağlı diğer etmenler ile bir ilişkisinin olmadığı itiraz edilemez bilimsel bir gerçektir. Sadece farklılıklar ya da üstünlükler düşünüldüğünde kadın ve erkek arasında anatomik farklılıklar ve bazı beyin bölgelerinde farklı bağlantıların olduğu bunların da nöroplastisite yani beyin esnekliği sayesinde değiştirilebileceği unutulmamalıdır (Uzbay, 2018).

\section{Kadın ve Erkek Beyninin Bilişsel İşlev Farklılıklan}

Nörogörüntüleme cihazları ile araştırma yapan nörobilimciler araştırma sonuçlarına göre kadın beyninin erkek beynine göre daha geniş bir alana yayıldığını ve daha fazla bağlantıya sahip olduğunu bulgulamışlardır. Ayrıca kadınlarda, sağ ve sol yarı kürenin birbiri ile bağlantısını sağlayan doku ve lifler sayıca daha fazla ve kalın olduğundan kadınların farklı kaynaklardan daha fazla bilgiyi bir araya getirebildikleri görülmüş̧ür (Barletta, 2003, s.26-27). Duyguların oluşması ve ifade edilmesinde temel beyin yapılarından biri amigdaladır. Örneğin; dışa dönük kişilik yapısına sahip bireylerde amigdalanın mutlu yüz ifadelerine verdiği tepki o denli yüksektir (Canli vd. 2002, s.2191). Erkeklerin ve kadınların duygularını işlemelerinde de farklılıklar vardır. Kadınlarda duygusal hafıza yani duyguların hatırlanması erkeklere göre daha iyidir (Bradley vd. 2001, s.312-315).

Doğumlarının üzerinden kısa bir süre geçen bebekler ile yapılan incelemede; kız bebekler, diğer bebeklerin yüz ifadelerine ve ağlamalarına erkek bebeklere oranla daha fazla tepki göstermiştir. Özellikle kız çocuklarının 
daha 1 yaşındayken bile gerilim ve stres belirtilerine tepki verdiği belirtilmiştir. Doğumdan sonraki ilk 3 ay içerisinde kız bebeklerde $\% 400$ oranında artan göz teması kurma yeteneğinin aynı süre içerisinde erkek bebeklerde bir farklılık oluşturmadığ ifade edilmiştir (Leeb ve Rejskind, 2004, s.7; McClure, 2000 'den akt. Brizendine, 2012, s.35). Yetişkinlerle yapılan yüz tanıma çalışmasında; katılımclara internet ortamından alınan 24 kadın ve 24 erkek görseli gösterilmiştir. Ancak, saç stillerinin cinsiyeti tahmin etmede etkili olabileceği düşüncesi ile görseller üzerindeki saç bölümleri program aracılığı ile silinmiş ve yapılan araştırma sonucunda erkek katılımcılar, erkek yüzüne ait görselleri tanımada kadın katılımclarda kadın yüzüne ait görselleri tanımada daha başarılı olmuştur (Wright ve Sladden, 2003, s.105-112). Bebekler üzerinde yapılan başka bir araştırmada; kız bebeklerin oyuncak bebeklerle oynamayı erkek bebeklere göre daha fazla tercih ettiği belirlenmiştir. Kız ve erkek bebekler, kendi cinslerine ait oyuncak bebekleri karşı cinse ait oyuncak bebeklere göre daha fazla tercih etmişlerdir (Roopnarine, 1986, s.67; Caldera vd. 1989, s.74).

Kadınlar ve erkekler arasında duyusal yönden de bazı farklılıklar bulunmaktadır. Kadınlar yüz ifadelerini okumada, koku ve tat algılamada, düşük sesleri duymada erkeklere kıyasla daha iyidir (Arıkan, 2011). Kadınların düşük sesleri erkeklere kıyasla iyi duydukları ayrıca dokunma duyularının da erkeklere oranla 10 kat daha duyarlı olduğu ifade edilmiştir (Amen, 2010, s.104). Yapılan araştırmalara göre erkekler bir ürüne dokunmak için genellikle davet beklerken, kadınlar davet beklemeden ürünü ellerine alıp incelemektedirler (Kotler ve Keller, 2018, s.250).

Bununla birlikte erkeklerin logolara, kadınlara oranla daha uzun süre odaklandıkları metinlere odaklanmalarının ise kadınlara oranla daha düşük düzeyde kaldığı tespit edilmiştir. Kadınların, metinlere odaklandıkları ve bir metni tamamladıktan sonra başka bir metne geçtikleri belirlenmiştir (Orquin ve Scholderer, 2011, s.61-63). Göz tarama verileri kullanılarak yapılan başka bir araştırmada üç tanınmış simanın yer aldığı iki farklı outdoor reklam görseli kadın ve erkek katılımclara gösterilmiştir. Kadın ünlünün yer aldığı görselde erkek katılımcılar, kadın katılımcılara kıyasla yüze daha fazla odaklanmıştır. Ancak diğer uyaranlar ile birlikte incelendiğinde erkekler logoya daha fazla odaklanırken; kadınlar slogan, yazı, ürün bilgisi, ürün özelliği gibi materyallere odaklanmışlardır (Yurdakul ve Girişken, 2017, s.188-195). 
Erkek bebekler cansız nesnelere ve mekanik objelerin hareketlerine dikkat gösterirken, kız bebekler insan yüzü ve hareketlerine daha eğilimlidirler (McGuinness ve Symonds, 1977, s.693; Malatesta ve Haviland, 1982, s.1002; Connellana vd. 2000, s.113-118; Barletta, 2003, s.31-32 ). Görsel, uzamsal ve geometrik becerilerde de kadın ve erkek beyni birçok araştırmaya tabi tutulmuştur. Farklı araştırma sonuçlarını inceleyen iki farklı meta analiz çalışmada; görsel ve uzamsal yeteneklerde erkeklerin kadınlara kıyasla daha başarılı olduğu sonucuna varılmıştır (Linn ve Petersen, 1985, s.1485-1494; Ayatola ve Adedeji, 2009' dan akt. Gültekin, 2014, s.27). Kadınların erkeklere göre zayıf olduğu alanlar; vücut hareketlerinin koordinasyonu, uzamsal yetenekler, aritmetik çözümleme ve mekanik kavrama konularıdır (Burstein vd., 1980 ve Deaux ve Kite, 1987'den akt. Koç, 2002, s.258). Ancak kadınlar, birbiri ile ilişkili ögeleri yerleştirme, karışık sunulan bilgileri ayırt etme, büyük bir resmin içine entegre etme ve ayrıntılara dikkat edip holistik düşünebilmede daha iyidirler (Laroche vd., 2000, s.503; Barletta, 2003, s.28).

Kadınlara ve erkeklere yönelik cinsel içerikli imajın bulunduğu 3 farklı markaya ait reklamlar katılımcılara izlettirilmiş ve araştırma sonucuna göre kadın katılımcıların odaklanma süreleri erkek katılımcılara göre daha düşük düzeyde kalırken; kadınların erkeklere göre daha fazla ayrıntıya dikkat ettiği tespit edilmiştir (Akgül, 2017, s.336-342). Afrikalı iki farklı kabile üzerinde yapılan bir araştırmada; erkeklerin daha üstün yön bulma kabiliyeti geliştirdikleri ayrıca daha gelişmiş bir mekansal algı kabiliyetine sahip oldukları ifade edilmiştir. Evrimsel psikolojide, erkeklerin daha uzun seyahatlere çıkıp daha fazla yol kat edebildiği bu nedenle adres ve yön bulma kabiliyetlerinin de kadınlardan daha iyi olduğu ileri sürülmüştür (Canoluk, 2016).

\section{Reklam Çekiciliği ve Reklam Stratejisi}

Sözlük anlamı olarak çekicilik; herhangi bir nesneye, kişiye veya mesaja dikkat çekmek, kişiler üzerinde etki oluşturmak, ilgi yaratmak amacı ile hazırlanmış içerik ya da görünümü ifade etmektedir. Reklam Terimleri ve Kavramları Sözlüğü'nde çekicilik, “Tüketicinin ürünü ya da hizmeti satın aldığı zaman kazanacağı yararlar. Bunlar, daha lezzetli yemekler, daha temiz giysiler vb. somut yararlar olabileceği gibi beğenilme, imrenilme gibi soyut yararlarda olabilir" şeklinde tanımlanmıştır (Gülsoy, 1999, s.24). Bir diğer tanımda 
ise; "Tüketicinin örtük arzularını uyandıracak bir gereksinimi reklam mesajına taşıyarak alıcıların ilgilerini, güdülenmelerini reklam aracılığıyla kışkırtan bir öge olarak" ifade edilmiştir (Moriarty, 2000, s.76). Reklam çekiciliğinde olması gereken özelliklerden birincisi; anlamlı olması, ürünün kullanıcıları için faydaları ve ilgi çekici noktalarının belirtilmiş olmasıdır. İkincisi, inandırıcı olmasıdır. Diğer bir ifadeyle tüketiciler ürünü veya hizmeti kullandıklarında beklentilerini karşılayacağına inanmalıdır. Üçüncü nokta ise; ürünün ayırt edici özelliğinin olmasıdır. Ürünün, rakip ürünlerden nasıl daha iyi olduğu açıkça gösterilmelidir (Kotler ve Armstrong, 2006, s.461). "Reklamın merkezi fikri ile çekicilik, mesajın yapısı için önemli bir ögedir. Çekiciliklerin seçiminde ürün grubu ve özellikleri de önemli bir ölçüttür." (Uztuğ, 2003, s.211). Reklamı yapılan ürünün, rakipleri ile arasında ayırt edilebilir bir fark olduğunu vurgulamak için ürünün güçlü bir reklam mesaj stratejisi ile planlanması gerekir. Hedef kitle ile kurulacak iletişimde öncelikli olarak hangi reklam mesaj stratejilerinin amaçlandığı belirlenmelidir (Kotler ve Armstrong, 2006, s.460).

\section{Araştırmanın Amacı ve Önemi}

$\mathrm{Bu}$ araştırmanin amacl; literatür incelemesi ile elde edilen cinsiyete yönelik farklılıklara ait bilgilerin nöropazarlama araştırma yöntemlerinden Eye Tracking Analiz Yöntemi ile desteklenip desteklenmediğini belirlemektir. Bu kapsamda dezenfektan reklamlarında kullanılan görsellerde; reklamda çekicilik ve strateji oluştururken dikkat sürelerinde ve sayılarında cinsiyete göre oluşan farklılıklar ortaya konulmaya çalışılmıştır. Araştırmada, hedef kitlenin Eye Tracking Analiz Yöntemi ile dezenfektan reklamlarında kullanılan görsellerin farkındalık düzeyleri araştırılmış ve görsel etki düzeyleri belirlenmiştir. Bu sebeple, dezenfektan reklamları aracılığı ile kadın ve erkeğin marka seçimindeki farklı kararlarının altında yatan gerçek sebepler anlaşılmaya çalışılmıştır. Böylece, dezenfektan reklamları üzerindeki görsel etki düzeylerinin cinsiyete göre farklılaşma düzeyleri tespit edilmiştir.

\section{Araştırmanın Yöntemi ve Örneklemi}

Araştırma kapsamında örneklem olarak T.C. Sağlık Bakanlığı'nın internet sitesinde izinli Dezenfektan ve Biyosidal Ürünler arasından el ve cilt tipine uy- 
gun olan toplamda 7 ayrı markaya ait dezenfektan markası rastsal olarak seçilmiştir. Araştırmada kullanılan görseller; Antımıc, Biorad, Bioxi, Crystalın, Dermosept, B-good, Maratem markalarına ait görsellerden oluşmaktadır. Araştırma yapılacak ürün belirlenirken; kadın ve erkek olmak üzere her iki tüketici gurubunun tüketiminde olan ortak bir ürünün seçilmesi mantığı ile hareket edilmiştir. Görseller belirlenirken; araştırmanın amacına uygun olacak şekilde her iki tüketici gurubuna da hitap edecek benzer özelliklere sahip görsellerin seçilmesine özen gösterilmiştir. Bu sebeple ürün görsellerinin metin, logo ve içerik olarak belirlenen ilgi alanlarında benzer özelliklere sahip olmasına dikkat edilmiştir. Araştırmada; göz takibi için ekran tabanll, hafif kayıt ünitesi ve basit, hızlı kalibrasyon, kolay ve sorunsuz veri toplama özellikleriyle Tobii Pro Eye Tracker cihazı kullanılmıştır. Göz izleme verilerinin toplanması Tobii Pro X2-60 ekran tabanlı göz takip cihazı ile bu verilerin analizi ve sunumu Tobii Pro Studio yazılımı ile gerçekleştirlmiştir.

Göz takip yöntemi, araştırmalarda katılımcıların görsel uyaranın hangi bölgesine, ne zaman ve hangi süre ile odaklandıklarına dair veri sunmaktadır (Özdoğan, 2008, s.135). Göz takip yöntemi odaklanma, sıçrama ve izlenen yol olmak üzere üç temel metrik ölçüm yapmaktadır. Odaklanma, o an için gözün nerede olduğunu ölçmektedir (Baş ve Tüzün, 2017, s.222). Gözün belli bir noktaya odaklanması 200-500 milisaniye (1 saniye: 1000 milisaniyedir.) aralığında o noktaya sürekli olarak bakıldığı anlamına gelmektedir. Odaklanma, tek bir nokta gibi anlaşılsa da aslında 75 küçük bölgeyi ifade etmektedir (Girişken, 2018, s.16). Belirlenen 7 adet el ve cilt tipi dezenfektan markalarına ait reklam görselleri 15 kadın ve 15 erkek olmak üzere toplam 30 katılımcıyla gerçekleştirilmiştir. Verilerin analizi sırasında öncelikle belirlenen markaların reklam görselleri üzerinde Görsel ve Yazı olmak üzere 2 ilgi alanı belirlenmiştir. Seçilen bu ilgi alanlarının Eye Tracking verilerine ait Isı Haritası (Heat Map), İlgi Alanı (Interest Area) sayısal verileri elde edilmiştir. Elde edilen veriler, belirlenen bu ilgi alanına göre Toplam Sabitlenme Süresi (Total Fixation Duration), Sabitlenme Sayısı (Fixation Count), Ortalama Ziyaret Süresi (Average Visit Duration) olarak değerlendirilmiştir.

Odaklanma ile elde edilen sonuçlar; beyin tarafından işlenmiş veriyi ifade etmektedir. Beyin kapasitesi optik sinirler aracılığı ile iletilen bütün bilgileri işleme yeteneğine sahip değildir. Bu noktada devreye seçici dikkat girmekte ve görselin yalnızca belirli kısmının işleme tabi tutulmasına, seçili olmayan bölgelerin ise baskılanmasına neden olmaktadır (Wedel ve Pieters, 2008, 
s.123-146). Deney sonrasında katılımcilarla 3 sorudan oluşan bir anket çalışması gerçekleştirilmiş ve anket çalışma sonuçları, Eye Tracking sonuçlarına ait veriler ile karşılaştırılmıştır. Katılımcılara yöneltilen anket soruları aşağıda verilmiştir:

- Görseller arasında aklınızda kalan bir marka var mı? Varsa nedir?

- Görsellerde dikkatinizi en çok çeken noktalar nelerdi?

- Görseller arasında en beğendiğiniz hangisiydi? Beğenmenizde etkili olan unsurlar nedir?

\section{Araştırma Soruları}

Belirlenen amaç kapsamında bu araştırmada aşağıdaki sorulara cevap aranmıştır;

- Dezenfektan reklamlarındaki sözel ve görsel mesajlara kadın ve erkek tüketicilerin dikkat ve odaklanma düzeylerinde farklılık var mıdır?

- Kadın ve erkek tüketicilerin dikkatini çekebilmek için dezenfektan reklamlarında marka ile ilgili iletilmek istenen önemli bir mesajn yeri, farklı olmalı midır?

- Kadın ve erkek tüketiciler dezenfektan reklam görsellerindeki hangi duyusal mesajlara tepki vermektedir?

- Kadın ve erkek tüketiciler dezenfektan reklamlarındaki görsellerde en çok nelere tepki vermektedir?

- Yapılan anket çalışması sonuçları ile Eye Tracking Analiz Yöntemi sonuçları arasında birbirini destekleyen sonuçlar ya da anlamlı farklılıklar var $\mathrm{m} 1$ ?

\section{Araştırmanın Analizi ve Bulguları}

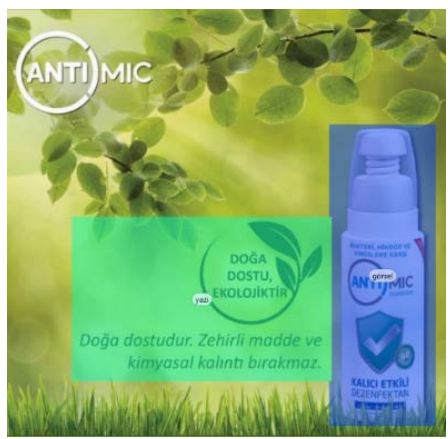

Şekil 1. Antımıc Markasına Ait İlgi Alanı Belirlenen Eye Tracking Görseli 
Şekil 1.'de Antimic markalı ürüne ait görselin Eye-Tracking verileri incelendiğinde; görsel ve yazı olmak üzere 2 ilgi alanı belirlenmiştir. Elde edilen veriler, belirlenen bu ilgi alanına göre değerlendirilmiştir. Bu bilgiler doğrultusunda;

Toplam odaklanma süresinin görselin olduğu alana 0,94 sn. $(\% 35,88)$ ve yazının olduğu alana $1,68 \mathrm{sn}$. $(\% 64,12)$ olduğu tespit edilmiştir.

Toplam odaklanma sayısı olarak bakıldığında; görselin olduğu alana 2,83 kez ve yazının olduğu alana 5,4 kez sabitlenmenin olduğu görülmüştür.

Ayrıca, Toplam odaklanma süresine kadın ve erkek katılımcı olarak bakıldığında; görsele kadınların 1,17 sn. erkeklerin ise 0,71 sn. odaklandıkları tespit edilmiştir. Bununla birlikte, yazının olduğu alana kadınların 1,87 sn. erkeklerin ise 1,49 sn. odaklanma gösterdiği tespit edilmiştir.

Toplam odaklanma sayısına kadın ve erkek katılımc olarak bakıldığında; görselin olduğu alana kadınların 2,9 kez; erkeklerin ise 2,8 kez odaklandıkları görülmüştür. Bununla birlikte, yazının olduğu alana kadınların 5,6 kez; erkeklerin ise 5,2 kez odaklanma gösterdiği tespit edilmiştir.

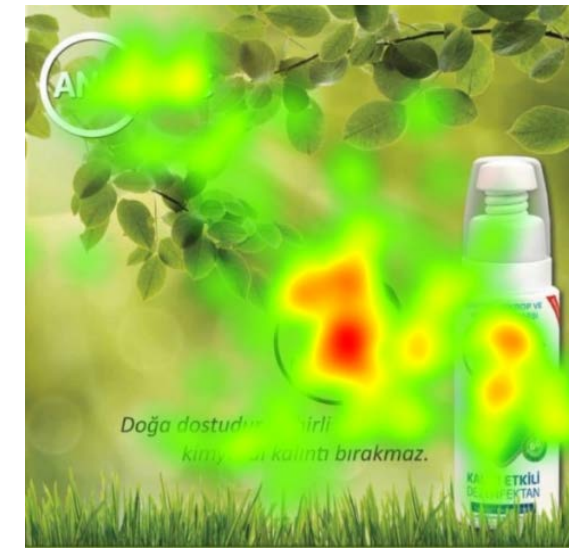

Şekil 2. Antımıc Markasına Ait Kadın

Katılimcilarn Heat Map

Verileri

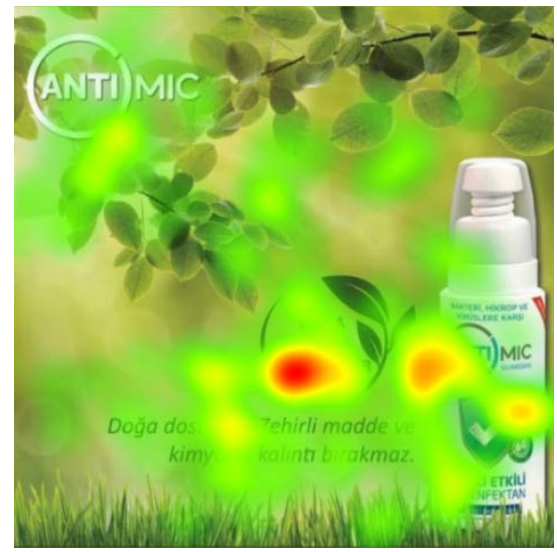

Şekil 3. Antımıc Markasına Ait Erkek

Katılimcilarn Heat Map Verileri

Şekil 2.'de Antımıc markalı ürünün kadınlara ait Heat Map (Isı Haritası) görseli verilmiştir. Görsel incelendiğinde; kadın katılımcıların ilk olarak ürünün özelliklerine vurgu yapan yazı ve slogana odaklandıkları, ikinci olarak ürünün ambalajına ve son olarak da sol üst köşede yer alan logoya baktıkları görülmektedir. 
Şekil 3.'te Antımıc markalı ürünün erkeklere ait Heat Map (Isı Haritası) görseli verilmiştir. Görsel incelendiğinde; erkek katılımcıların tıpkı kadın katılımcılar gibi ilk olarak yazı ve slogana odaklandıkları, ikinci olarak ürünün ambalajinda yer alan logoya ve son olarak da yine sol üst köşede yer alan logoya baktıkları görülmektedir. Ancak, erkek katılımcıların ısı haritasında odaklandıklarınoktalara bakıldığında kadın katılımcılara göre daha geniş bir alanı taradıkları görülmektedir.

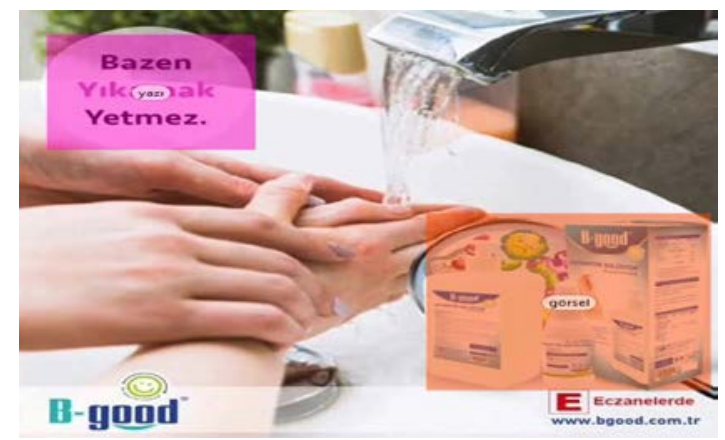

Şekil 4. B-good Markasına Ait İlgi Alanı Belirlenen Eye Tracking Görseli

Şekil 4.'te B-good markalı ürüne ait görselin Eye-Tracking verileri incelendiğinde; görsel ve yazı olmak üzere 2 ilgi alanı belirlenmiştir. Elde edilen veriler, belirlenen bu ilgi alanına göre değerlendirilmiştir. Bu bilgiler doğrultusunda;

Toplam odaklanma süresinin görselin olduğu alana 0,73 sn. $(\% 48,99)$ ve yazının olduğu alana $0,76 \mathrm{sn}$. (\%51,01) olduğu tespit edilmiştir.

Toplam odaklanma sayısı olarak bakıldığında; görselin olduğu alana 3,03 kez ve yazının olduğu alana 3,20 kez sabitlenmenin olduğu görülmüştür.

Ayrıca, Toplam odaklanma süresine kadın ve erkek katılımcı olarak bakıldığında; kadınların görselin olduğu alana 1,04 sn. erkeklerin ise 0,42 sn. odaklandıkları tespit edilmiştir. Bununla birlikte, yazının olduğu alana kadınların 0,97 sn. erkeklerin ise 0,55 sn. odaklanma gösterdiği tespit edilmiştir.

Toplam odaklanma sayısına kadın ve erkek katılımcı olarak bakıldığında; görselin olduğu alana kadınların 3,5 kez; erkeklerin ise 2,5 kez odaklandıkları görülmüştür. Bununla birlikte, yazının olduğu alana kadınların 3,6 kez; erkeklerin ise 2,7 kez odaklanma gösterdiği tespit edilmiştir. 


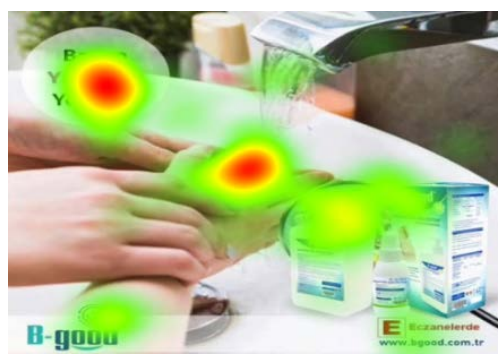

Şekil 5. B-good Markasina Ait Kadın Katılimcilarnn Heat Map Verileri

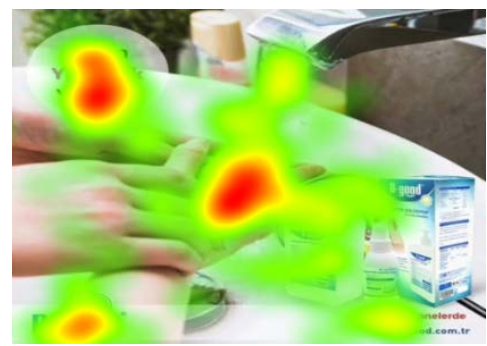

Şekil 6. B-good Markasina Ait Erkek Katılımcilarn Heat Map Verileri

Şekil 5.'te B-good markalı ürünün kadınlara ait Heat Map (Isı Haritası) görseli verilmiştir. Görsel incelendiğinde; kadın katılımcıların ilk olarak el görseli üzerine yoğunlaştıkları ikinci odaklanmalarının sol üst köşede yer alan slogana, son olarak da ürünün ambalaj ve logosunda gerçekleşen odaklanmaları görülmektedir.

Şekil 6.'da B-good markalı ürünün erkeklere ait Heat Map (Isı Haritası) görseli verilmiştir. Görsel incelendiğinde; erkek katılımcların ilk olarak el y1kama görseli ve sloganı benzer yoğunlukta taradıkları ikinci odaklanmalarının ise markaya ait logoda olduğu görülmektedir. Kadın katılımcıların ısı haritası görselleri ile karşılaştıııldığında erkek katılımcların daha geniş bir alanı taradıkları ve ürüne erişimi içeren internet adresine daha fazla odaklandıkları görülmektedir.

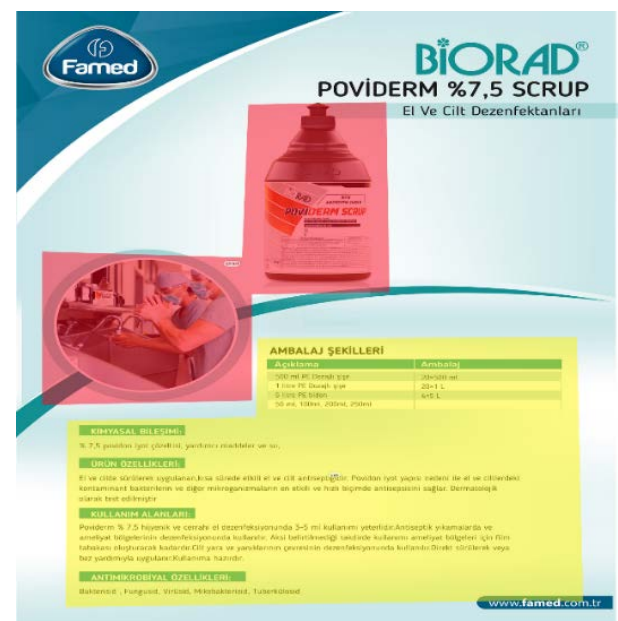

Şekil 7. Biorad Markasına Ait İlgi Alanı Belirlenen Eye Tracking Görseli 
Şekil 7.'de Biorad markalı ürüne ait görselin Eye-Tracking verileri incelendiğinde; görsel ve yazı olmak üzere 2 ilgi alanı belirlenmiştir. Elde edilen veriler, belirlenen bu ilgi alanına göre değerlendirilmiştir. Bu bilgiler doğrultusunda;

Toplam odaklanma süresinin görselin olduğu alana 1,68 sn. (\%52,50) ve yazının olduğu alana $1,52 \mathrm{sn}$. $(\% 47,50)$ olduğu tespit edilmiştir.

Toplam odaklanma sayısı olarak bakıldığında; görselin olduğu alana 7,63 kez ve yazının olduğu alana 6,83 kez sabitlenmenin olduğu görülmüş̧ür.

Ayrıca, Toplam odaklanma süresine kadın ve erkek katılımcı olarak bakıldığında; görsele kadınların 1,81 sn. erkeklerin ise 1,54 sn. odaklandığı tespit edilmiştir. Bununla birlikte, yazının olduğu alana kadınların 1,92 sn. erkeklerin ise 1,12 sn. odaklama gösterdiği tespit edilmiştir.

Toplam odaklanma sayısına kadın ve erkek katılımcı olarak bakıldığında; görsele kadınların 7,2 kez; erkeklerin ise 8,1 kez odaklandıkları görülmüştür. Bununla birlikte, yazının olduğu alana kadınların 7,4 kez; erkeklerin ise 6,3 kez odaklanma gösterdiği tespit edilmiştir.

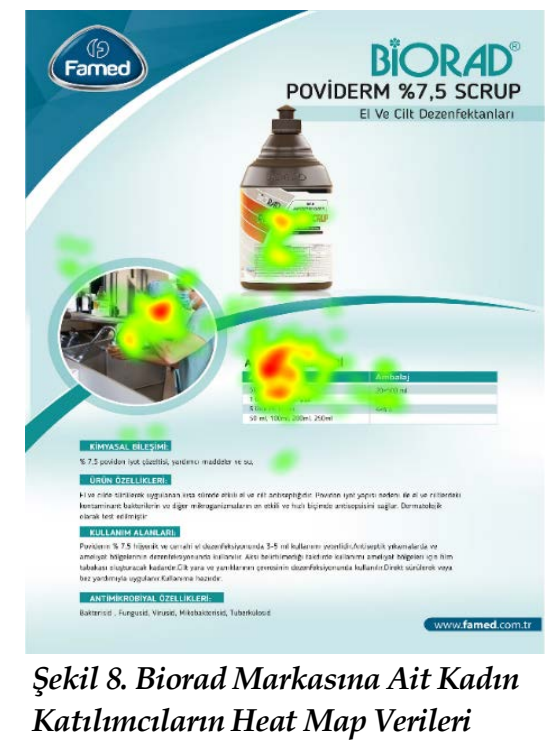

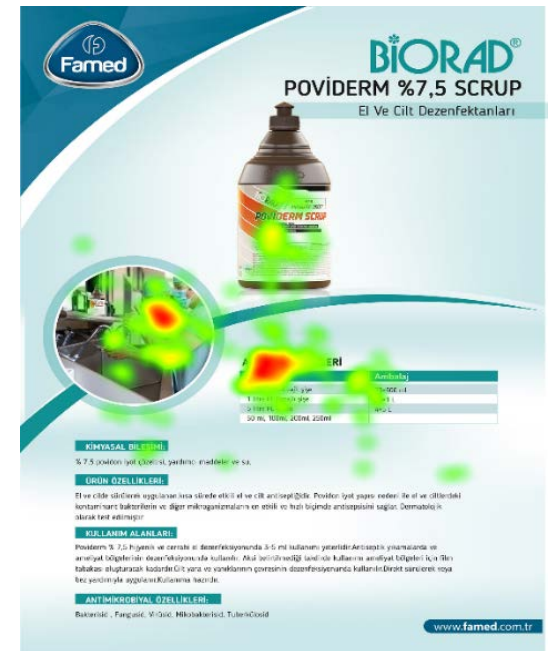

Şekil 9. Biorad Markasina Ait Erkek Katılimcilarm Heat Map Verileri

Şekil 8.'de Biorad markalı ürünün kadınlara ait Heat Map (Isı Haritası) görseli verilmiştir. Görsel incelendiğinde; kadın katılımcıların ilk olarak 
ürünle ilgili içerik bilgilerinin yer aldığı yazı alanına ikinci odaklanmaları dezenfektan kullanan sağlık çalışanlarının bulunduğu alana ve son olarak da ürünün ambalajında gerçekleşen bir odaklanmaları görülmektedir.

Şekil 9.'da Biorad markalı ürünün erkeklere ait Heat Map (Isı Haritası) görseli verilmiştir. Görsel incelendiğinde; erkek katılımcıların ilk olarak ürünle ilgili içerik bilgilerinin yer aldığı yazı alanına ikinci odaklanmaları dezenfektan kullanan sağlık çalışanlarının bulunduğu bölgeye ve son olarak da ürünün ambalajında gerçekleşen bir odaklanmaları görülmektedir. Erkek katılımcılar yine bu görselde de kadın katılımclara göre daha geniş bir alanı tarama eğilimindedir.

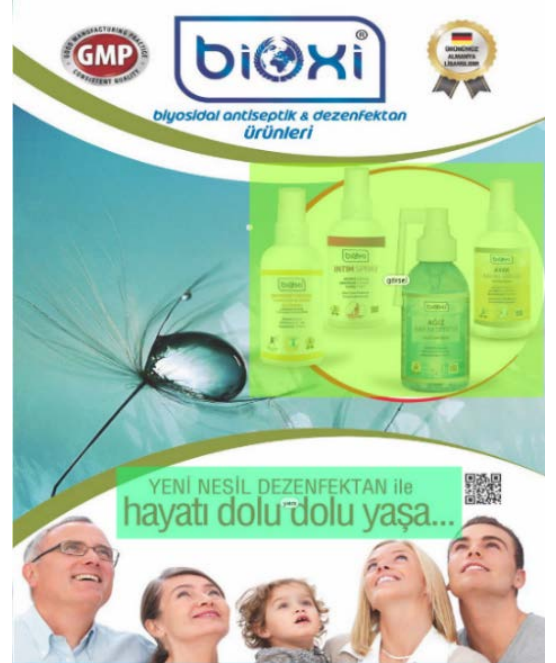

Şekil 10. Bioxi Markasına Ait İlgi Alanı Belirlenen Eye Tracking Görseli

Şekil 10.'da Bioxi markalı ürüne ait görselin Eye-Tracking verileri incelendiğinde; görsel ve yazı olmak üzere 2 ilgi alanı belirlenmiştir. Elde edilen veriler, belirlenen bu ilgi alanına göre değerlendirilmiştir. Bu bilgiler doğrultusunda;

Toplam odaklanma süresinin görselin olduğu alana 1,04 sn. $(\% 62,65)$ ve yazının olduğu alana 0,62 sn. $(\% 32,35)$ olduğu tespit edilmiştir.

Toplam odaklanma sayısı olarak bakıldığında; görselin olduğu alana 3,90 kez ve yazının olduğu alana 3,13 kez sabitlenmenin olduğu görülmüş̧ür.

Ayrıca, Toplam odaklanma süresine kadın ve erkek katılımcı olarak bakıldığında; görsele kadınların 1,32 sn. erkeklerin ise 0,75 sn. odaklandıkları 
tespit edilmiştir. Bununla birlikte, yazının olduğu alana kadınların 0,62 sn. ve erkeklerin de yine 0,62 sn. odaklanma gösterdiği tespit edilmiştir.

Toplam odaklanma sayısına kadın ve erkek katılımcı olarak bakıldığında; görselin olduğu alana kadınların 4,2 kez; erkeklerin ise 3,6 kez odaklandıkları görülmüştür. Bununla birlikte, yazının olduğu alana kadınların 3,1 kez; erkeklerin ise 3,2 kez odaklanma gösterdiği tespit edilmiştir.

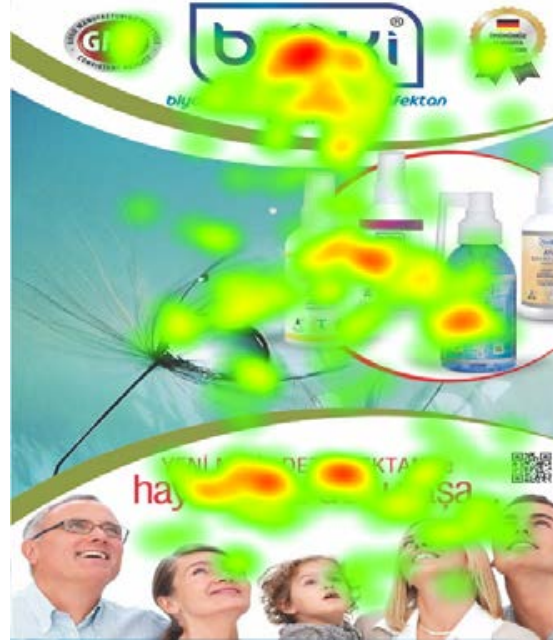

Şekil 11. Bioxi Markasına Ait Kadın Katılımcılarn Heat Map Verileri

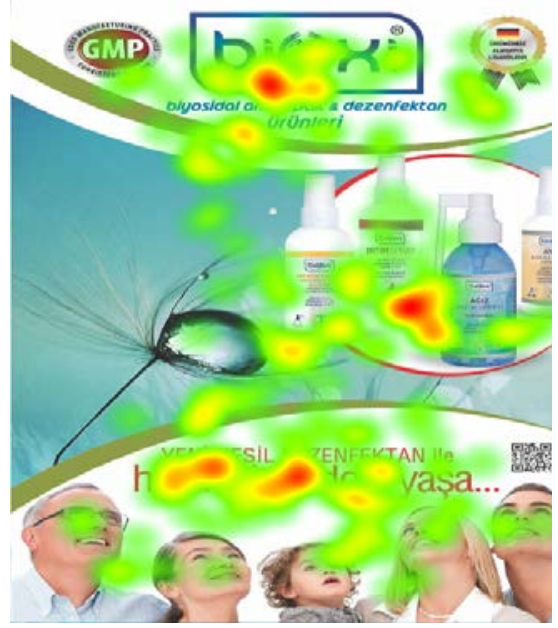

Şekil 12. Bioxi Markasına Ait Erkek Katılımolarn Heat Map Verileri

Şekil 11.'de Bioxi markalı ürünün kadınlara ait Heat Map (Isı Haritası) görseli verilmiştir. Görsel incelendiğinde; kadın katılımcıların ilk olarak ürünün logosuna, ikinci odaklanma amabalaj ve çevresine ve son olarak da yazı alanı bölgesinde yer alan sloganda odaklanmaları görülmektedir. Ayrıca görsel üzerinde kadın katılımcılar erkek yüzlerine kıyasla hemcinslerine ait yüzleri daha fazla taramışlardır. Kadın katılımcılar, görsel üzerinde ürünün menşei hakkında bilgi içeren alanı, su damlasını ve ilaç-kozmetik sektöründe insanların doğrudan sağllğını ilgilendiren ürünlerin güvenilir ortamlarda üretildiğini gösteren alanları da inceleyerek daha fazla detaya odaklanmışlardır.

Şekil 12.'de Bioxi markalı ürünün erkeklere ait Heat Map (Isı Haritası) görseli verilmiştir. Görsel incelendiğinde; erkek katılımcıların kadınlarda olduğu gibi ilk olarak yazı alanı bölgesinde yer alan slogana odaklandıkları, ikinci odaklanma ambalaj ve logoda birbirine yakın oranda görülmektedir. Ayrıca 
görsel üzerinde erkek katılımclar kadınların aksine hem erkek hem kadın yüzlerinde tarama gerçekleştirmişlerdir.

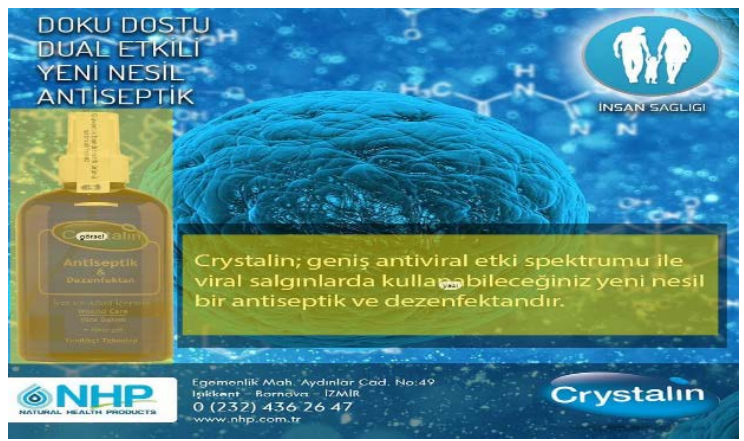

Şekil 13. Crystalın Markasına Ait Ilgi Alann Belirlenen Eye Tracking Görseli

Şekil 13'te Crystalın markalı ürüne ait görselin Eye-Tracking verileri incelendiğinde; görsel ve yazı olmak üzere 2 ilgi alanı belirlenmiştir. Elde edilen veriler, belirlenen bu ilgi alanına göre değerlendirilmiştir. Bu bilgiler doğrultusunda;

Toplam odaklanma süresinin görselin olduğu alana 0,93 sn. $(\% 61,59)$ ve yazının olduğu alana 0,58 sn. $(\% 38,41)$ olduğu tespit edilmiştir.

Toplam odaklanma sayısı olarak bakıldığında; görselin olduğu alana 3,33 kez ve yazının olduğu alana 2,97 kez sabitlenmenin olduğu görülmüsstür.

Toplam odaklanma süresine kadın ve erkek katılımcı olarak bakıldığında; görsele kadınların 1,12 sn. erkeklerin ise 0,74 sn. odaklandıkları görülmüştür. Bununla birlikte, yazının olduğu alana kadınların 0,74 sn. erkeklerin $0,41 \mathrm{sn}$. odaklanma gösterdiği tespit edilmiştir.

Toplam odaklanma sayısına kadın ve erkek katılımcı olarak bakıld1ğında; görselin olduğu alana kadınların 3,5 kez; erkeklerin ise 3,1 kez odaklandıkları görülmüş̧ür. Bununla birlikte, yazının olduğu alana kadınların 3,3 kez; erkeklerin ise 2,6 kez odaklanma gösterdiği tespit edilmiştir. 


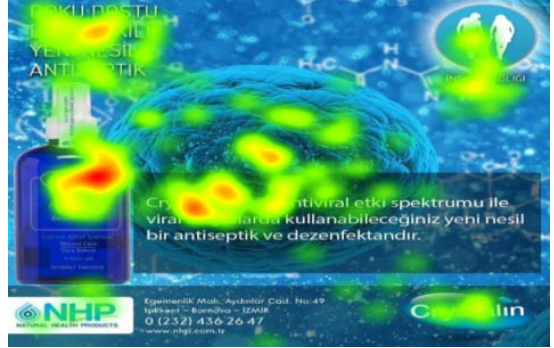

Şekil 14. Crystalın Markasına Ait

Kadın Katılımcilarn Heat Map Verileri

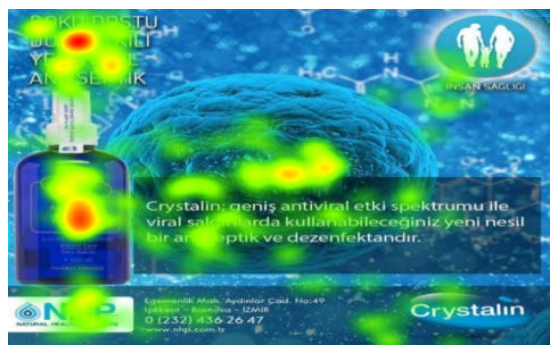

Şekil 15. Crystalın Markasına Ait Erkek Katılımcılarn Heat Map Verileri

Şekil 14.'te Crystalın markalı ürünün kadınlara ait Heat Map (Isı Haritası) görseli verilmiştir. Görsel incelendiğinde; kadın katılımcıların ilk olarak ürünün ambalajına ikinci odaklanmaları ürünün içeriği ile ilgili açıklama yazısına ve son olarak da sol üst bölgede yer alan slogan kısmında gerçekleşen bir odaklanmaları görülmektedir. Ayrıca insan sağlığına vurgu yapan yazı alanı da erkek katılımcılara göre kadın katılımcıların daha fazla dikkatini çekmiştir.

Şekil 15.'te Crystalın markalı ürünün erkeklere ait Heat Map (Isı Haritası) görseli verilmiştir. Görsel incelendiğinde; erkek katılımcıların ilk olarak ambalajın üst kısmında yer alan slogana ikinci odaklanmaları ambalaja ve son olarak da ürünün içeriği ile ilgili açıklama yazısına yakın bölgede gerçekleşen bir odaklanmaları görülmektedir. Ayrıca erkek katılımcılar adres ve iletişim bilgilerini içeren alana daha uzun süre odaklanmışlardır.

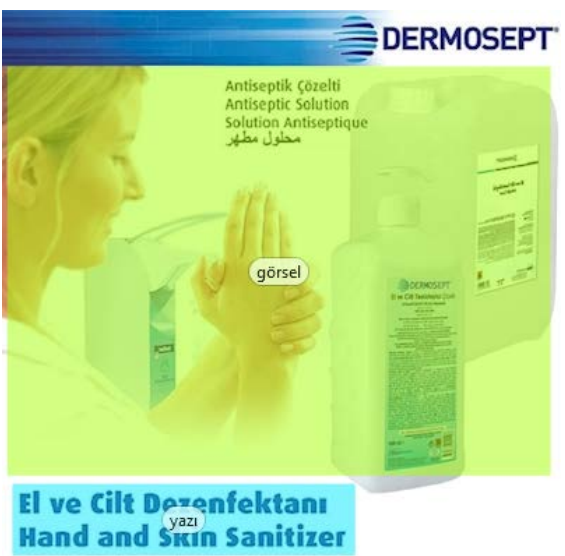

Şekil 16. Dermosept Markasına Ait İlgi Alanı Belirlenen Eye Tracking Görseli 
Şekil 16.'da Dermosept markalı ürüne ait görselin Eye-Tracking verileri incelendiğinde; görsel ve yazı olmak üzere 2 ilgi alanı belirlenmiştir. Elde edilen veriler, belirlenen bu ilgi alanına göre değerlendirilmiştir. Bu bilgiler doğrultusunda;

Toplam odaklanma süresinin görselin olduğu alana 2,50 sn. $(\% 87,72)$ ve yazının olduğu alana $0,35 \mathrm{sn}$. $(\% 12,28)$ olduğu tespit edilmiştir.

Toplam odaklanma sayısı olarak bakıldığında; görselin olduğu alana 11,57 kez ve yazının olduğu alana 2,07 kez odaklanmanın olduğu görülmüştür.

Ayrıca, Toplam odaklanma süresine kadın ve erkek katılımcı olarak bakıldığında; görsele kadınların 2,98 sn. erkeklerin ise 2,02 sn. odaklandıkları tespit edilmiştir. Bununla birlikte, yazının olduğu alana kadınların 0,51 sn. erkeklerin ise $0,19 \mathrm{sn}$. odaklanma gösterdiği tespit edilmiştir.

Toplam odaklanma sayısına kadın ve erkek katılımcı olarak bakıldığında; görsel alana kadınların 12,3 kez; erkeklerin ise 10,9 kez odaklandıkları görülmüştür. Bununla birlikte, yazının olduğu alana kadınların 2,5 kez; erkeklerin ise 1,7 kez odaklanma gösterdiği tespit edilmiştir.

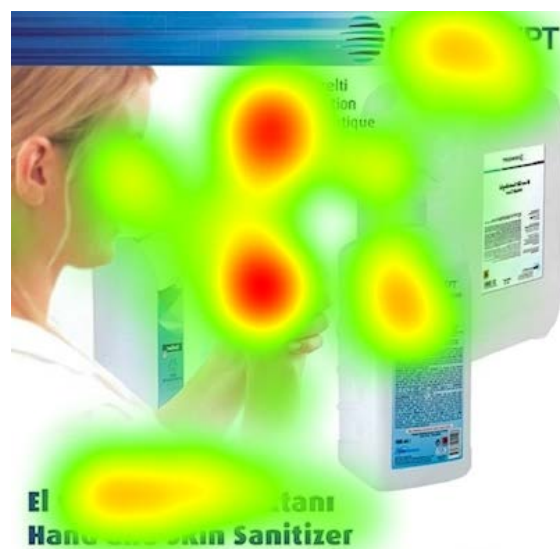

Şekil 17. Dermosept Markasına Ait

Kadın Katılımcilarn Heat Map verileri

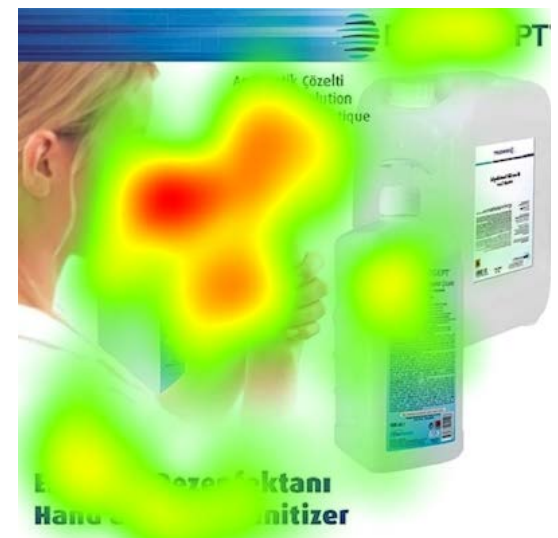

Şekil 18. Dermosept Markasina Ait Erkek Katılımcılarn Heat Map Verileri

Şekil 17.'de Dermosept markalı ürünün kadınlara ait Heat Map (Isı Haritası) görseli verilmiştir. Görsel incelendiğinde; kadın katılımcılar ilk olarak el görselinin olduğu bölge ve onun hemen üstüne yerleştirilen ürün hakkında 
bilgi veren yazı alanına ikinci odaklanmaları ürünün ambalajina ve son olarak da sol alt köşede yer alan ürün hakkında bilgi veren yazı alanında gerçekleşen bir odaklanma görülmektedir.

Şekil 18.'de Dermosept markalı ürünün erkeklere ait Heat Map (Isı Haritası) görseli verilmiştir. Görsel incelendiğinde; erkek katılımcıların ilk olarak kadın yüzünün olduğu alana ve bakışının yöneldiği bölgeye ikinci odaklanmaları ambalaj, marka ismi, ürünün içeriği ile ilgili bilgi veren yazı alanına benzer oranlarda görülmektedir. Yine bu görsel üzerinde de erkek katılımc1lar daha geniş bir alanı tarama eğilimindedir.

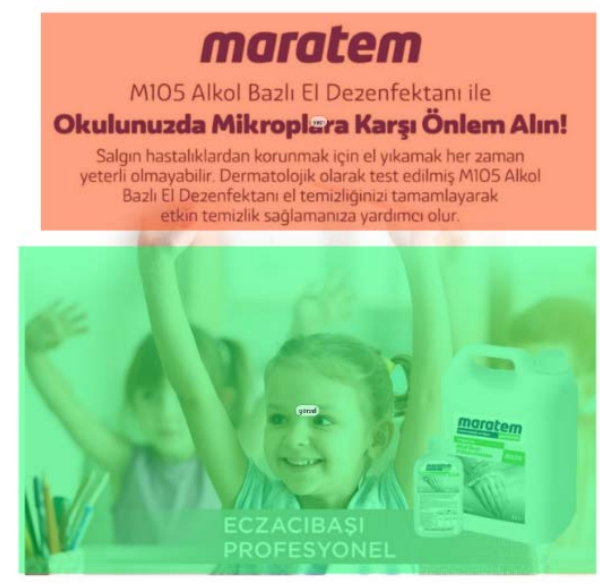

Şekil 19. Maratem Markasına Ait İlgi Alanı Belirlenen Eye Tracking Görseli

Şekil 19.'da Maratem markalı ürüne ait görselin Eye-Tracking verileri incelendiğinde; görsel ve yazı olmak üzere 2 ilgi alanı belirlenmiştir. Elde edilen veriler, belirlenen bu ilgi alanına göre değerlendirilmiştir. Bu bilgiler doğrultusunda;

Toplam odaklanma süresinin görselin olduğu alana 1,62 sn. $(\% 46,29)$ ve yazının olduğu alana 1,88 sn. (\%53,71) olduğu tespit edilmiştir.

Toplam odaklanma sayısı olarak bakıldığında; görselin olduğu alana 5,97 kez ve yazının olduğu alana 7,67 kez odaklanmanın olduğu görülmüş̧ür.

Ayrıca, toplam odaklanma süresine kadın ve erkek katılımcı olarak bakıldığında; görsele kadınların 1,91 sn. erkeklerin ise 1,32 sn. odaklandıkları tespit edilmiştir. Bununla birlikte, yazının olduğu alana kadınların 1,94 sn. erkeklerin ise 1,82 sn. odaklanma gösterdiği tespit edilmiştir. 
Toplam odaklanma sayısına kadın ve erkek katılımcı olarak bakıldığında; görselin olduğu alana kadınların 6,3 kez; erkeklerin ise 5,6 kez odaklandıkları görülmüştür. Bununla birlikte, yazının olduğu alana kadınların 7,8 kez; erkeklerin ise 7,5 kez odaklanma gösterdiği tespit edilmiştir.

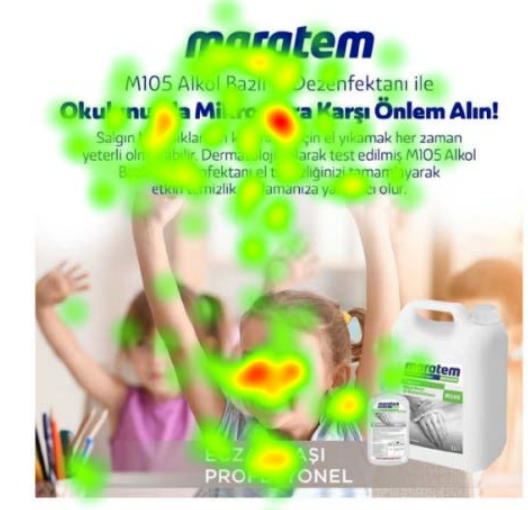

Şekil 20. Maratem Markasına Ait Kadin Katılımoılarn Heat Map Verileri

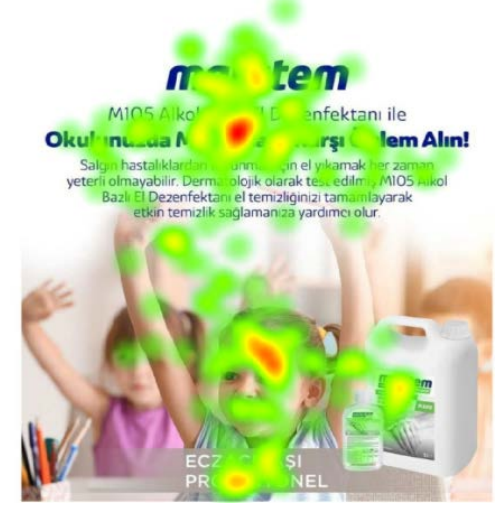

Şekil 21. Maratem Markasina Ait Erkek Katılımcılarn Heat Map Verileri

Şekil 20.'de Maratem markalı ürünün kadınlara ait Heat Map (Isı Haritası) görseli verilmiştir. Görsel incelendiğinde; kadın katılımcların ilk olarak görselde yer alan kız çocuğunun yüz bölgesine, ikinci odaklanmaları ürün hakkında bilgi veren sloganı da içeren yazı alanına ve son olarak da ürünün ambalajında gerçekleşen bir odaklanmaları görülmektedir. Ayrıca Kadınlar bu görselde ellerin olduğu bölgede daha fazla tarama gerçekleştirmiş ve sol alt köşede yer alan kalem görsellerini de inceleyerek daha fazla detaya dikkat etmişlerdir

Şekil 21.'de Maratem markalı ürünün erkeklere ait Heat Map (Isı Haritası) görseli verilmiştir. Görsel incelendiğinde; erkek katılımcıların ilk olarak marka bilgisi ve sloganında yer aldığı yazı alanına, ikinci odaklanmaları kız çocuğunun yer aldığı yüz bölgesine ve son olarak da ürünün ambalajında yer alan logoda gerçekleşen bir odaklanma görülmektedir. Isı haritası detaylı olarak incelendiğinde erkek katılımcllar bu görsel üzerinde de daha geniş bir alanı tarama eğilimindedir.

15 adet kadın ve 15 adet erkeğe gösterilen 7 adet dezenfektan reklamından elde edilen görsellere ve yazılara odaklanma sayıları ve odaklanma süreleri arasında cinsiyete göre 0.05 anlamlılık düzeyinde istatistiki bir farklılık olup 
olmadığını test etmek için Bağımsız t-testi uygulanmıştır. Tablo 1.'de gösterildiği üzere, görsellere ve yazılara odaklanma sayıları arasında kadın ve erkekler arasında anlamlı bir farklılığa rastlanılmazken ( $p>0.05)$, görsellere ve yazılara odaklanılan sürelerde anlamlı farklılıklar olduğu tespit edilmiştir $(\mathrm{p}<0.05)$. Kadınlar için görsellere odaklanma süresi $(x=1.62$;ss=1.18) erkeklerinkinden daha uzun ( $\mathrm{x}=1.07 ; \mathrm{ss}=0.97)$ bulunmuştur. Benzer şekilde kadınların yazılara odaklanma sürelerinin $(x=1.22 ; s s=1.10)$ de erkeklerinkinden ( $x=0.88$; ss=0.99) daha uzun olduğu görülmüştür.

Tablo 1. Kadınlarnn ve Erkeklerin Odaklanma Süreleri Fark Testi Analizi

\begin{tabular}{|c|c|c|c|c|c|c|c|c|}
\hline & \multirow{2}{*}{ Gruplar } & \multirow{2}{*}{$N$} & \multirow{2}{*}{$\overline{\mathrm{X}}$} & \multirow{2}{*}{ SS } & \multirow{2}{*}{$\mathrm{Sh}_{\overline{\mathrm{x}}}$} & \multicolumn{3}{|c|}{$t_{\text {Testi }}$} \\
\hline & & & & & & $t$ & $S d$ & $p$ \\
\hline \multirow{2}{*}{$\begin{array}{l}\text { Görsellere } \\
\text { Odaklanma Süresi }\end{array}$} & Kadın & 105 & 1.62 & 1.18 & 0.11 & \multirow{2}{*}{3.675} & \multirow{2}{*}{208} & \multirow{2}{*}{0.00} \\
\hline & Erkek & 105 & 1.07 & 0.97 & 0.95 & & & \\
\hline \multirow{2}{*}{$\begin{array}{l}\text { Yazılara Odaklanma } \\
\text { Süresi }\end{array}$} & Kadın & 105 & 1.22 & 1.10 & 0.10 & \multirow{2}{*}{2.326} & \multirow{2}{*}{208} & \multirow{2}{*}{0.02} \\
\hline & Erkek & 105 & 0.88 & 0.99 & 0.09 & & & \\
\hline
\end{tabular}

\section{Değerlendirme ve Sonuç}

Kadının ve erkeğin dikkat ile odaklanma sürelerini, ilgi düzeylerini, reklam görsel/yazı mesajları üzerinden yorumlayan bu çalışma nöropazarlama araştırma yöntemlerinden göz izleme tekniği ile gerçekleştirilmiştir. Araştırma sonuçları göstermektedir ki görsel olarak tasarlanmış reklam mesajında cinsiyete göre algılanan farklılıklar bulunmaktadır. Bu durum farklı odaklanma süreleri ve sayıları, farklı odaklanma alanları ile görülmektedir. Çıkan sonuçlar ve bulgular kısa bir anket çalışması ile karşılaştırılmış ve sonuçlar aşağıda tartışmaya açlmıştır.

\section{Dezenfektan reklamlarnndaki sözel ve görsel mesajlara kadın ve erkek tüke- ticilerin dikkat ve odaklanma düzeylerinde farklılık var mudır?}

Odaklanma sürelerine bakıldığında sözel ve görsel mesajlara kadın ve erkek tüketicilerin dikkat ve odaklanma düzeylerinde anlamlı farklılıklar görülmektedir. Araştırma sonucunda görsel ve yazı olarak belirlenen her iki ilgi alanı içinde kadınların erkeklere kıyasla daha yüksek oranda odaklanma gösterdikleri tespit edilmiştir. Odaklanma süre ve sayıları ile birlikte değerlendirildiğinde kadınların odaklanılan objeler üzerinde daha fazla düşündüğü ve 
detaylı bir inceleme gerçekleştirdikleri, erkeklerin ise görseldeki ögeleri hızlıca taradıkları ve daha kısa süreli bir odaklanma gösterdikleri tespit edilmiştir.

Kadınların görsele odaklanma süresine ait ortalamaları 1.62 saniye iken yazı alanına odaklanma süresine ait ortalamaları 1.22 saniyedir. Erkeklerin görsele odaklanma süresine ait ortalamaları 1.07 saniye iken yazı alanına odaklanma süresine ait ortalamaları 0.88 saniyedir.

Kadınların görsele odaklanma sayısına ait ortalamaları 5.7 kez iken yazı alanına odaklanma sayısına ait ortalamaları 4.7 kezdir. Erkeklerin görsele odaklanma sayısına ait ortalamaları 5.2 kez iken yazı alanına odaklanma sayısına ait ortalamaları 4.1 kezdir.

\section{Kadın ve erkek tüketiciler dezenfektan reklamlarındaki görsellerde en çok ne- lere tepki vermektedir?}

Antımıc, B-good, Biorad, Dermosept ve Maratem markalarına ait görsellerin ısı haritası bulguları incelendiğinde erkek katılımcılar kadınlara kıyasla görsellerin daha geniş bir alanını taramışlardır. Bu bilgiler ışı̆̆ında literatürde yer alan erkeklerin daha geniş bir alanı tarama, görsel ve uzamsal becerilerde dikkatli olma eğiliminde oldukları bulguları ile örtüşmektedir (Linn ve Peterson, 1985, s.1485-1494; Ayatola ve Adedeji, 2009'dan akt. Gültekin, 2014, s.27).

B-good ve Crystalın markalarına ait görsellerin ısı haritası bulgularında erkek katılımcıların ürüne erişimi içeren adres, iletişim ve internet uzantısı gibi alanlara kadın katılımcılardan daha fazla tarama gösterdikleri tespit edilmiştir. Bu bulgu uzak mesafelere açılma davranışları, adres ve yön bulma yeteneklerinin erkeklerde daha gelişmiş olduğunu açıklayan evrimsel psikoloji araştırma sonuçları ile literatür bulgularını destekler niteliktedir (Canoluk, 2016).

Bioxi ve maratem markalarına ait kadın ve erkek $15 ı$ haritaları karşılaştıııldığında bu görseller üzerinde bulunan çoklu uyaranlar sebebi ile kadın katılımcılar; ürünün menşeine dair bilgi içeren alanı, su damlası, ilaç-kozmetik sektöründe insanların doğrudan sağllğını ilgilendiren ürünlerin güvenilir ortamlarda üretildiğini gösteren logo ve kalemleri de inceleyerek daha fazla detaya odaklanmışlardır. Bu bilgi literatürde yer alan kadınların erkeklere kı- 
yasla karışık sunulan bilgileri ve ayrıntıları analiz etmede daha başarılı olduğu bulguları ile uyuşmaktadır (Laroche vd., 2000, s.503; Barletta, 2003, s.28; Akgül, 2017, s.336-342).

Kadın ve erkek tüketiciler dezenfektan reklam görsellerindeki hangi duyusal mesajlara tepki verir?

B-good, Biorad, Bioxi, Dermosept ve Maratem markalarının kadın ve erkek ısı haritası karşılaştırmalarında kadınların dokunma duyusunu harekete geçiren el yıkama görselleri, su damlası gibi alanlarda erkeklere kıyasla yüksek oranda bir odaklanma gerçekleştirdikleri ayrıca kadınların anket yanıtlarında da dokunma duyusuna dair benzer ifadeleri kullanması kadınların dokunma duyularının erkeklere kıyasla daha gelişmiş̧ olduğunu belirten literatür bilgileri ile örtüşmektedir (Amen, 2010, s.104; Kotler ve Keller, 2018, s.250).

Kadın ve erkek tüketicilerin dikkatini çekebilmek için dezenfektan reklamlarında marka ile ilgili iletilmek istenen önemli bir mesajın yeri, farklı olmalı midır?

Bioxi markasına ait 1sı haritası görseli incelendiğinde kadın katılımcıların hemcinslerinin yüz bölgesini daha fazla taradıkları ancak erkek katılımcıların ısı haritasında her iki cinse ait yüz bölgelerini taradıkları görülmektedir. Bu bilgi kadın katılımcıların hemcinslerinin yüzünü tanıma ve odaklanma eğiliminde oldukları literatür bilgilerini desteklerken erkeklerin daha çok kendi hemcinslerinin yüzünü tanıma ve odaklanma bilgisi ile çelişmektedir (Caldera vd. 1989, s.74; Wright ve Sladden, 2003, s.105-112). Erkek katılımciların yazı ilgi alanına kıyasla görsel ilgi alanlarına daha fazla odaklandıkları görülmektedir. Ayrıca her iki hedef grupta Bioxi marka görselinde insanların bakış yönünü takip etme eğilimindedir.

Yapılan anket çalışması sonuçlan ile Eye Tracking analiz yöntemi sonuçları arasında birbirini destekleyen sonuçlar ya da anlamlı farkhlıklar var mı?

Odaklanma süre ve sayılarına ait ortalamalar anket yanıtları ile karşılaştırıldığında anket sonuçlarında kadınların dikkatini çeken noktaları belirtirken çocuk yüzü, eller, su damlası gibi görsellerden bahsetmesi verilerin birbiri ile örtüştügüunü göstermektedir. Ancak erkek katılımcıların anket sonuçlarında ağırlıklı olarak dikkatlerini çeken noktalar arasında bilgi içerikli yazılardan 
bahsetmesine karşın odaklanma süre ve sayılarında görsel ilgi alanı verileri daha yüksek bulunmuştur.

Anket çalı̧̧masında, görseller arasında aklınızda kalan bir marka ismi var mı? Sorumuza kadın katılımcilardan 6'sı marka isimlerini hatırlamış ancak 9 kadın katılımcı marka ismini hatırlamadıklarını belirtmiştir. Yine erkek katılımcıların 4'ü marka ismini hatırlamış ancak 11 erkek katılımcı marka ismini hatırlamadıklarını belirtmiştir. Katılımcılar görseller üzerinde dikkatlerini en çok çeken noktalar hakkında detaylı açıklama yaparken marka ismi hatırlamada daha düşük düzeyde hatırlama gerçekleştirmişlerdir.

Görsel olarak hazırlanan basılı reklamlarda, ürün ambalajlarında hedef kitlenin dikkatini çekecek, hedef kitlenin yüksek ilgi düzeyine sahip olacak görsel alan ve yazı alanı hazırlanması satış rakamları için oldukça önemlidir. Sonuçlar göstermektedir ki kadın katılımcılar reklam görsellerini incelerken daha fazla zaman harcamaktadır. Kadın tüketicilere ürünün faydaları ve kazanımları anlatılırken detaylardan bahsetmek, erkek katılımcların daha düşük dikkat ve odaklanma süreleri düşünüldüğünde kısa ve öz bir anlatım ya da dikkat çekici bir slogan veya aynı etkide bir görsel kullanımı önerilmektedir. Kadınlar ve erkekler arasındaki algısal ve bilişsel farklılıkların belirlenmesi pazarlama disiplini açısından önem arz etmektedir. Çünkü kadın ve erkek tüketicilerin hormonal farklılıklarından, beyin yapısına ve işlevine, dikkat ve odaklanma sürelerinden, ayrıntılı düşünme yeteneklerine kadar birçok etken pazarlama iletişimine verdikleri tepkiyi de etkilemektedir. Elde edilen bilgiler; kadın ve erkek tüketicilere ulaşmada, reklam stratejisi ve reklam çekiciliği oluşturmada pazarlama araştırmacılarının çalışmalarına etki edecektir. Bu çalışma, reklam çekiciliği ve reklam stratejisi belirlemede cinsiyet alg1sının görsel olarak hazırlanmış reklamlar aracılığı ile sınandığı bir çalışmadır. Farklı mecralar için hazırlanmış görsel ve işitsel ögeler içeren reklamlar, örneğin televizyon reklamlarının etkisi ya da sosyal medya için hazırlanan reklamların etkisi de cinsiyet farklılıklarına dair bulguların farklı bir boyuta ulaşmasını sağlayabilir. Bu çalışmada her iki cinsiyete hitap eden bir ürün kategorisi seçilmiştir. Görseller hedef grup tarafından çok fazla bilinmeyen el ve cilt tipi dezenfektan markaları arasından tercih edilmiştir. Başka bir çalışma farklı bir ürün kategorisinde ya da bilinen bir marka özelinde, farklı reklam formatlarında, farklı demografik özellikler (yaşlı, genç, evli, bekar vb.) gruplar üzerinde gerçekleştirilebilir. 


\title{
EXTENDED ABSTRACT
}

\section{The Evaluation of the Perception of Advertising Attractiveness and Advertising Strategies in Different Genders over Disinfectant Ads}

\author{
Ayşe Sucu -Özge Baruönü - Nurcan Yücel \\ Doğuş University, Frrat University
}

The concept of gender, which is a crucial market segmentation variable in marketing research, has had an increase of interest of both academics and advertising professionals in determining effective advertising strategies suitable for target markets. Marketing communication and advertising fields have especially tried to describe the similarities and differences between the genders. Many studies conducted through different disciplines (Linn and Petersen, 1985; Roopnarine, 1986; Wilson, 1989; Bradley et al., 2001; Koç, 2002; Leeb and Rejskind, 2004; Çiftçi, 2011; Pace, 2011; Şener, 2015 ; Uzbay, 2018) revealed that there are differences in processing information and communication in women and men. Investigating these findings is an important option for those operating in the field of marketing and advertising to communicate with the target audience and create a compelling advertising message. With the use of new technological methods in marketing research, businesses and researchers who care about what consumers think about their products and services have started to use neuromarketing methods and tools in their studies.

As an important marketing tool that guides purchasing behaviour, ads have the power to influence the target audience with determined strategies. Addressing the wishes and needs of the target audience and creating effective advertising made it mandatory to use up-to-date research methods in studies. For this reason, thanks to these innovative trends in the field of marketing, the research at hand was carried out with the method of eye-tracking.

There are significant differences in the brain structure of women and men. Although the differences in behaviours of individuals depend on the interaction between hormones and the brain, hormones determine how the neural network will settle while the baby is still in the mother's womb (Moir and 
Jessel, 1992, p.41-42). It is an undeniable scientific fact that intelligence has nothing to do with gender or other gender-related factors. When only differences or superiorities are considered, it should be kept in mind that there are anatomical differences between men and women, such as different connections in some regions of the brain which can be changed by neuroplasticity which is brain flexibility (Uzbay, 2018).

There are some sensory differences between men and women. Women are better at reading facial expressions, perceiving smell and taste, and hearing low voices than men (Arikan, 2011). However, it was found that men focused on logos longer than women, whereas their focus on texts remained lower than women. It was also confirmed that women focused on texts and moved on to other texts when they were finished (Orquin and Scholderer, 2011, p.6163).

The central idea of advertising and attractiveness is an important element of the structure of the message. Product group and features are also important criteria in the selection of attractiveness. (Uztuğ, 2003, p. 211). In order to emphasize that the advertised product has a distinct difference from its competitors, the product should be planned with a strong advertising message strategy. In the communication to be established with the target audience, it should be determined primarily which advertising strategies are aimed for the message (Kotler and Armstrong, 2006, p.460).

In the light of the information obtained from the literature, it was aimed to determine whether the information on gender differences in this study is supported by the Eye-Tracking Analysis Method, one of the neuromarketing research methods. In this context, while creating attraction and strategy in the visuals used in disinfectant advertisements, it was tried to reveal the differences in attention periods and number of occurrences by gender. In the research, the awareness levels of the visuals used in the disinfectant advertisements of the target audience with the Eye Tracking Analysis Method were investigated and the visual impact levels were determined.

Within the scope of the research, disinfectant brands belonging to 7 different brands were chosen randomly among the authorized Disinfectants and Biocidal Products on the website of the Ministry of Health as a sample. Visuals used in the research consist of images of Antimic, Biorad, Bioxi, Crystalın, Dermosept, B-good, and Maratem. While determining the product to be re- 
searched; It is based on the logic of choosing a common product that is consumed by both consumer groups, male and female. The eye-tracking method provides data on where the visual stimulus is focused on, and for what duration. Eye-tracking method makes three basic metric measurements: focus, leap and path (Baş and Tüzün, 2017, p. 222).

Considering the Eye Tracking and Heat Map data, it is seen that there are significant differences in the attention and focus levels of male and female consumers in terms of focus times, verbal and visual messages. As a result of the research, it was determined that women showed a higher rate of focus compared to men in both areas of interest: visuals and texts. When evaluated together with the duration and number of times of focus, it was found that women thought more about the focused objects and carried out a detailed examination, while men scan the visual items quickly and show a shorter focus.

This study is an experiment in which the perception of gender in determining advertising attractiveness and advertising strategy is tested through visually prepared advertisements. Advertisements that contain visual and auditory elements prepared for different media, such as the effect of television advertisements or the effect of advertisements prepared for social media, may also lead to a different dimension of gender differences.

\section{Kaynakça / References}

Afyon Medikal. (t.y). Afyon antiseptik crystalin. https://www.afyonmedikalfirma.com/2020/03/afyon-antiseptik-crystalin.html adresinden erişilmiştir.

Akgül, D. (2017). Basılı reklamların etkisini cinsiyet ve gürültü belirler mi?: Göz takip sistemi ile uygulama. Uluslararası İktisadi ve İdari İncelemeler Dergisi, 16.Ui் Özel Sayı, 331-348

Amen, D. G. (2010). Aşık beyin. (İ. Erdener, Çev.) İstanbul: Pegasus Yayınları.

Antimiconline. (t.y). Twitter. https://twitter.com/antimiconline adresinden erişilmiştir.

Arıkan, R. N. (2011). Kadın beyni erkek beyni. 10 Nisan 2020 tarihinde https://www.milliyet.com.tr/ pembenar/uzm-psikolog-psikoterapist-rusen-nur-arikan/kadin-beyni-erkek-beyni-1343245 10 Nisan 2020 tarihinde adresinden erişilmiştir. 
Barletta, M. (2003). Marketing to women: How to understand, reach, and increase your share of the world's largest market segment. Chicago: Dearborn Trade Publishing.

Baş, T. ve Tüzün, H. (2017). Tüketicileri ve ürün kullanımlarını analiz etmek için göz izleme yönteminin kullanılması. Tüketici Yazıları, 4, 217-234.

B-GOOD (2019). Yikamak yetmez bazen. [Videoblog], Facebook. https://www.facebook.com/bgoodcomtr/videos/yikamak-yetmez-bazen-ellerin-ve-cildin-lokal-dezenfeksiyonunda-kullan \%C4\%B11\%C4\%B1rsa\%C4\%9Fl\%C4\%B1k/707539836392445/adresinden erişilmiştir.

Bradley, M. M., Codispoti, M., Sabatinelli, D. ve Lang, P. J. (2001). Emotion and motivation II: sex differences in picture processing. Emotion. American Psychological Association, 1, 300-319.

Brizendine, L. (2012). Kadın beyni. (Z. Heyzen, Çev.) İstanbul: Ateş Say Yayınları.

Caldera, Y. M., Huston, A. C. ve O’Brein, M. (1989). Social interactions and play patterns of parents and toddlers with feminine, masculine nnd neutral toys. Child Development, 60, 70-76.

Canli, T., Sivers, H., Whitfield, S. L., Gotlib, I.H. ve Gabrieli, J.D. (2002). Amygdala response to happy faces as a function of extraversion. Science, 296, 2191.

Canoluk, U. (2016) Erkeklerde yer-yön bulma kabiliyeti eş bulmak için mi gelişti? 01 Mart 2020 tarihinde https://evrimselpsikoloji.blogspot.com/2016/06/erkeklerde-yer-yon-bulma-kabiliyeti-es.html adresinden erişilmiştir.

Connellana, J., Baron-Cohena, S., Wheelwrighta, S., Batkia, A. ve Ahluwalia, J. (2000). Sex differences in human neonatal social perception. Infant Behavior $\mathcal{E}$ Development, 23, 113-118

Çiftçi, M. A. (2011). Öğretmenlerin ve farkl sosyo-ekonomik düzeye sahip anne-babalarn cinsiyet rolleri algısının 60-72 ay arası çocuklarmn oyuncak tercihleri ve akran etkileşimleri ile ilişkisinin incelenmesi. Çukurova Üniversitesi, SBE, Yüksek Lisans Tezi, Adana.

FAMED. (t.y). Poviderm \% 7,5 Scrup hand and skin disinfectants. 05 Mart 2020 tarihinde https://www.famed.com.tr/en/products/high-level-hygiene-and-disinfectant-products/poviderm-7-5-scrup adresinden erişilmiştir. 
FindGlocal. (t.y). Bioxi Biyosidal Doğal Dezenfektan Ürünleri 05 Mart 2020 tarihinde http://www.findglocal.com/TR/Anamur/1485713835084223/Bioxi-Biyosidal-Do $\% C 4 \% 9$ Fal-Dezenfektan-\%C3\%9Cr\%C3\%BCnleri? of chl jschl tk =a81ee9ce08dd26904bbf128effff9cc2ccc6ca081590332659-0-Aay0ZCOhEFV_OCZ5yzEu32OedDefreuA7Dkz9ZgF6R RqmqdRQuQDEyEeTXjLfG7nxQJq-Tu CeoGKEChf_FBuGJtDZJRqpSE91mHNLR-KyhaEWvG33iEp1P4liBXb91kfLFOLBQmyJy8nkchgitr728Y 6x1qU41LbCIOVZR4RUBZjhZoxa8a5aOYOEDUdLCxYuF227cQyHokesDoB92wrKnpd2zUi31NwxscpKtDeeyQoi0vusTOKEv2bgoIxvEy2PGuIErCQDCDEWmJOsXnIV06hSDD10i7OiHxNz5wFsGf2nTTpaTIuOwLyNwJ-zU6KEljb4hyzWhwagNQ3tUGn8-mJCPJvHddd7AB2nYe0avMVEN 5ON-6vytfQzVcFd5PmQ17gszybryQWmTssNTtPuW14na4tV MnVTmSIi4wYuSg9y0pYak8uMsrA9w adresinden erişilmiştir.

Girişken, Y. (2018). Gerçeği algıla. İstanbul: Beta Yayınları.

Gülsoy, T. (1999). Reklam terimleri ve kavramlarn sözlüğü. İstanbul: Adam Yayınları.

Gültekin, M. (2014). Bilimsel araştırmalarda kadın-erkek farklılıkları. Aile Akademisi Derneği, Bursa, 1-38.

Koç, E. (2002). The impact of gender in marketing communications: The role of cognitive and affective cues. Journal of Marketing Communications, 8, 257-275.

Kotler, P. ve Armstrong, G. (2006). Principles of marketing. United Kingdom: Pearson Prentice Hall.

Kotler, P. ve Keller, K.L. (2018). Pazarlama yönetimi. (İ. Kurçova, Çev.) İstanbul: Beta Yayıncilık.

Laroche, M., Saad, G., Cleveland, M. ve Browne, E. (2000). Gender differences in information research strategies for a christmas gift. Journal of Consumer Marketing, 17, 500-524.

Leeb, R. T. ve Rejskind, F. G. (2004). Here's looking at you, kid! A longitudinal study of perceived gender differences in mutual gaze behavior in young infants. Sex Roles, 50, 1-14.

Linn, M.C. ve Petersen, A.C. (1985). Emergence and characterization of sex differences in spatial ability: A meta-analysis. Child Development, 56, 1479-1498.

Malatesta C. Z. ve Haviland, J. M. (1982). Learning display rules: The socialization of emotion expression in infancy. Child Development, 53, 991-1003.

McGuinness, D. ve Symonds, J. (1977). Sex differences in choice behaviour: The object-person dimension. Perception, 6, 691-694. 
Moir, A. ve Jessel, D. (1992). Beynimizdeki cinsellik. (E. Eden, Çev.) İstanbul:Cep Kitapları A.Ş.

Moriarty, S. E. (2000). Creative advertising theory and practice. New Jersey: Prentice Hall.

N11. (t.y). Anti-Bakteriyel \& Dezenfektan 05 Mart 2020 tarihinde https://urun.n11.com/anti-bakteriyel-ve-dezenfektan/dermosept-el-vecilt-dezenfektani-5000-ml-P403535921 adresinden erişilmiştir.

N11. (t.y). Eczacıbaşı Maratem M105 Alkol Bazlı El Dezenfektanı. 05 Mart 2020 tarihinde https://urun.n11.com/anti-bakteriyel-ve-dezenfektan/maratemm105-alkol-bazli-el-dezenfektani-5-lt-eczacibasi-P428861023 adresinden erişilmiştir.

Orquin, J. ve Scholderer, J. (2011). Attention to health cues on product packages, Journal of Eyetracking. Visual Cognition and Emotion, 1, 59-63.

Özdoğan, B. (2008). Göz izleme ve pazarlamada kullanılması üzerine kavramsal bir çalışma. Ticaret ve Turizm Ĕ̆itim Fakültesi Dergisi, 2, 134-147.

Pace, E. (2011). Alışverişte kadın erkek. (Ö. Tüzel Akal, Çev.) İstanbul: Optimist Yayınları.

Roopnarine, J. L. (1986). Mothers and fathers behaviors toward the toy play of their infant sons and daughters, Sex Roles, 14, 59-68.

Şener, G. (2015). Reklam bilgi işleme stratejilerinde cinsiyet farklllıkları: Seçicilik hipotezi çerçevesinde reklam tepkisine yönelik deneysel bir çalışma. Anadolu Üniversitesi SBE, Doktora Tezi, Eskişehir.

T.C Sağlık Bakanlığı. (t.y). Dezenfektanlar ve genel biyosidal ürünler. 02 Mart 2020 tarihinde https://hsgm.saglik.gov.tr/tr/cevresagligi-biyosidal/dezenfektanlarve-genel-biyosidal-\%C3\%BCr\%C3\%BCnler-birimi/dezenfektanlar-ve-genel-biyosidal-urunler.html adresinden erişilmiştir.

Ural, T. (2008). Pazarlamada yeni yaklaşım: nöropazarlama üzerinde kurumsal bir değerlendirme. Ç.Ü. Sosyal Bilimler Enstitüsü Dergisi, 17, 421-432.

Uzbay, T. (2018). Kadın beyni-erkek beyni ne kadar benzer ne kadar farklı? 19 Nisan 2020 tarihinde https://tayfunuzbay.com/kadin-beyni-erkek-beyni-ne-kadarbenzer-ne-kadar-farkli.html adresinden erişilmiştir.

Uztuğ, F. (2003). Markan kadar konuş: Marka iletişimi stratejileri. İstanbul: MediaCat Kitapları.

Wedel, M. ve Pieters, R. (2008). A review of eye-tracking research in marketing. Bingley: Emerald Group Publishing Limited, 4, 123-146.

Wilson, G. D. (1989). The great sex divide: A study of male-famele differences. London: Peter Owen. 
Wright, D. B. ve Sladden, B. (2003). An own gender bias and the importance of hair in face recognition. Acta Psychologica, 114, 101-114.

Yurdakul, D. ve Girişken Y. (2017). Görsel odaklanmada kadın ve erkekler arası farklılıklar: Basılı reklam görselleri üzerine bir çalışma. Marmara Business Review, 2, 183-200.

\section{Kaynakça Bilgisi / Citation Information}

Sucu, A., Baruönü, Ö. ve Yücel, N. (2021). Reklam çekiciliğinin ve reklam stratejilerinin farklı cinsiyetlerde yarattığı algının dezenfektan reklamları üzerinden değerlendirilmesi. OPUS-Uluslararası Toplum Araştırmaları Dergisi, 17(34), 1275-1305. DOI: 10.26466/opus.833604 